Evans, D. G. \& Wardlaw, A. C. (1952). J. gen. Microbiol. 7, 397-408.

\title{
In vitro and in vivo Properties of Culture Filtrates of Bacillus subtilis with High Gelatinase Activity
}

\author{
By D. G. EVANS and A. C. WARDLAW \\ Department of Bacteriology, University of Manchester
}

\begin{abstract}
SUMMARY : Concentrated culture filtrates from Bacillus subtilis, with high gelatinase activity, disintegrated hide powder although unable to attack native collagen; they also haemolysed the red blood cells of a number of species. The concentrated filtrates were dermonecrotic in rabbits and lethal on intravenous injection into mice. There was no conclusive evidence that the factors responsible for any of these effects were antigenic. Although each of the in vitro and in vivo activities was destroyed by heat, the haemolytic activity was more resistant than the others. Fresh normal sera from many species inhibited each of the three properties shown in vitro. Tests with gelatinase showed that inhibition occurred rapidly and in multiple proportions. The inhibitory action was diminished by heat and storage and was distinct from the antitryptic property of serum.
\end{abstract}

It is well known that many species of the genus Bacillus have the property of liquefying gelatin, and Bertiau (1914) originally showed that the enzyme involved in this reaction was present in culture filtrates separated from the bacilli. The activities of the enzyme, apart from its ability to liquefy gelatin, have not been extensively studied, and little is known of its action on other substrates. It was therefore considered desirable, especially in view of the interesting observations made during the last few years on the proteolytic enzymes of the related genus Clostridium, to investigate the activities of the gelatinase of certain species of Bacillus. The initial work reported here was made with culture filtrates of $B$. subtilis.

\section{PREPARATION AND CONCENTRATION OF CULTURE FILTRATES}

The medium found to be most suitable for preparing filtrates of high gelatinase activity consisted of $1 \%$ Evans peptone in normal saline adjusted to $\mathrm{pH} 7 \cdot 8$. The medium was distributed in $250 \mathrm{ml}$. amounts in $20 \mathrm{oz}$. medical flats and autoclaved at $10 \mathrm{lb}$. for $10 \mathrm{~min}$. No improvement in gelatinase production was obtained with media prepared either from other brands of peptone or from nutrient broth, and neither gelatin nor glucose added to the medium enhanced the production of enzyme.

Ten authentic strains of $B$. subtilis, from the Wellcome Laboratories and the National Collection of Type Cultures, were tested and found to show considerable differences in their ability to produce gelatinase. One of the most active strains, NCTC 3610, was chosen and used throughout this work.

Each bottle of medium was inoculated with $1 \mathrm{ml}$. of an overnight culture and incubated at $37^{\circ}$ in an almost horizontal position to expose the maximum surface to air. Preliminary titrations by the method described below showed that the gelatinase titre reached its maximum in 2-4 days; this time was 
subsequently chosen for separating the filtrates, which was done through a Seitz EK filter. The gelatinase in the filtrate was concentrated by the addition of $500 \mathrm{~g}$. ammonium sulphate $/ \mathrm{l}$., which precipitated the enzyme without appreciable loss of potency. The precipitate was filtered on Whatman no. 15 filter-paper and dialysed overnight against running tap-water to remove ammonium sulphate. The residue was then centrifuged to remove particulate material and the clear supernatant fluid dried from the frozen state.

\section{IN VITRO PROPERTIES OF CULTURE FILTRATES}

\section{Action on gelatin}

Titration. A method of titrating gelatinase based on the Frazier (1926) technique was first investigated. Dilutions of culture filtrate were pipetted into Heatley cups fixed on to the surface of non-nutrient agar plates containing $0.5 \%(\mathrm{w} / \mathrm{v})$ gelatin. After overnight incubation at $37^{\circ}$ the plates were flooded with acid $\mathrm{HgCl}_{2}$ solution and the activity of the enzyme estimated from the highest dilution which inhibited around the cup a zone of precipitation. This method was not adopted as the errors involved were found to be considerable and exact end-points were difficult to read.

A more reliable method was devised in which the gelatinase activity of culture filtrates was estimated from their ability to liquefy gelatin solution under standard conditions. Dilutions of filtrate differing by $10-20 \%$ were made in tubes $1.7 \times 9 \mathrm{~cm}$. and to $1 \mathrm{ml}$. of each dilution, $1 \mathrm{ml}$. of $10 \%(\mathrm{w} / \mathrm{v})$ gelatin solution was added. The gelatin solution was prepared by dissolving flake gelatin (Griffin and Tatlock) in saline, adjusting to $\mathrm{pH} \mathbf{7 \cdot 8}$ and adding phenol to $0.5 \%(\mathrm{w} / \mathrm{v})$ as preservative. A control tube of $2 \mathrm{ml}$. of $1.5 \%$ gelatin in saline was included with each titration. The mixtures of filtrate and gelatin, together with the control, were incubated at $37^{\circ}$ in a waterbath for $1 \mathrm{hr}$. with periodic shaking and then transferred to a bath of ice water. The times taken for the mixtures to set to a consistency such that they failed to flow when the tubes were tilted horizontally were determined and plotted against the filtrate dilutions. A typical curve is shown in Fig. 1. The setting time of the control tube was also measured; this was consistently between 5 and 9 min., a time which lay on the steep part of the titration curve and enabled end-points to be read most accurately. The end-point was obtained from the graph by reading off the dilution of filtrate which gave the same setting time as the control. In the example shown in Fig. 1 the titre of the filtrate was $1 / 54$. It has been found convenient to express gelatinase activities in terms of the number of minimal gelatinase doses $/ \mathrm{ml}$. (m.g.d./ml.) which is the reciprocal of the titre and for the filtrate in Fig. 1 is 54 m.g.d. $/ \mathrm{ml}$. The majority of concentrated culture filtrates which we have prepared had a gelatinase activity such that a $1 \%$ solution of the dried material contained 200-500 m.g.d./ml.

Effect of time of incubation. In most cases titrations of gelatinase were done after $1 \mathrm{hr}$. incubation of enzyme and gelatin mixtures. The sensitivity of the reaction was, however, increased by Ionger periods of incubation, and Fig. 2 
indicates that there was a linear relationship between time of incubation and gelatinase titre. When it was necessary to measure low enzyme activities, which were not detected after $1 \mathrm{hr}$. incubation, a $24 \mathrm{hr}$. period was used.

Effect of $\mathrm{pH}$ value. Gelatinase titres did not vary appreciably when the mixtures of enzyme and gelatin were incubated within the $\mathrm{pH}$ range 6-8, but outside this range the titres were lower. Routine tests were made with mixtures at $\mathrm{pH} \mathbf{7 \cdot 8}$. The effect of the $\mathrm{pH}$ value on the stability of gelatinase was also determined. Portions of filtrate containing $32 \mathrm{~m} . \mathrm{g} . \mathrm{d} . / \mathrm{ml}$. were maintained at different $\mathrm{pH}$ values for $24 \mathrm{hr}$. at $10^{\circ}$ and the residual activity was titrated after the $\mathrm{pH}$ had been readjusted to $\mathbf{7 \cdot 8}$. It was found that little or no loss in activity occurred between $\mathrm{pH} 5 \cdot 0$ and $11 \cdot 0$, but that outside this range the loss in activity was rapid.

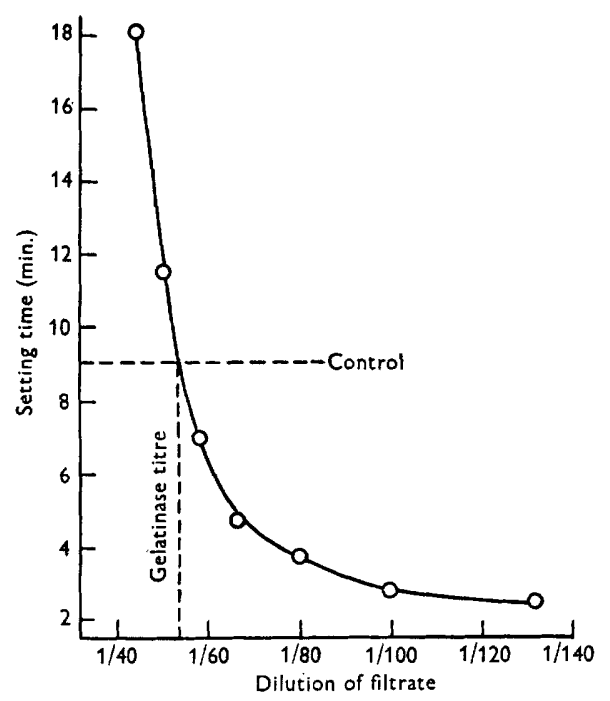

Fig. 1

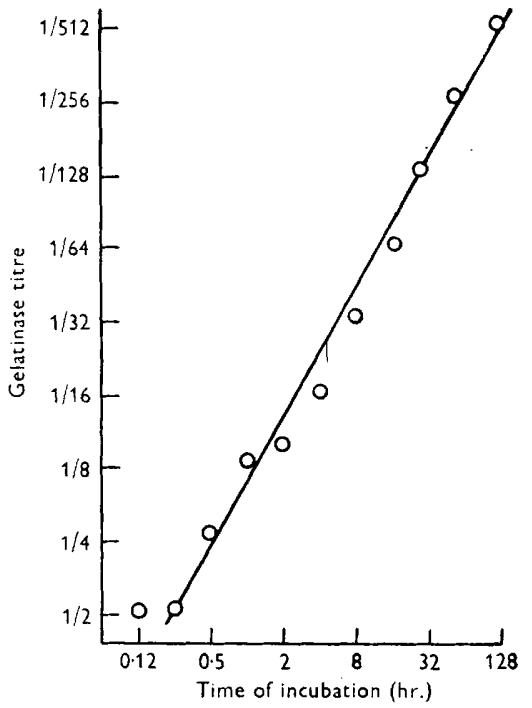

Fig. 2

Fig. 1. The relationship between setting time of gelatin and dilution of concentrated culture filtrate. The titre of this particular filtrate was $1 / 54$ since this dilution gave the same setting time as the control tube.

Fig. 2. The effect on the gelatinase titre of the time of incubation of filtrate with gelatin. Logarithmic scales are used for both axes.

Effect of heat. This was investigated with a saline solution of filtrate containing $\mathbf{5 0}$ m.g.d./ml. No detectable activity was lost when the solution was kept at room temperature for 1 week, or at $37^{\circ}$ for $\mathbf{2 4} \mathrm{hr}$. At higher temperatures, however, the enzyme was destroyed; in $2 \mathrm{hr}$. at $56^{\circ}$ the activity was decreased by $50 \%$ and at $65^{\circ}$ inactivation was complete in less than 10 min. (Table 1).

\section{Action on collagen and hide powder}

Collagen. Solutions of dried culture filtrate containing $500 \mathrm{~m} . \mathrm{g} . \mathrm{d} . / \mathrm{ml}$. of gelatinase were tested for their ability to disintegrate native collagen. Two collagen preparations were used: $(a)$ thin shavings cut longitudinally from 
fresh ox Achilles tendon; $(b)$ rat tail collagen 'paper' prepared by the method of Delaunay, Guillaumie \& Delaunay (1949). These preparations were suspended in the enzyme solutions and incubated at $37^{\circ}$. There was no evident disintegration of either of these substrates after $48 \mathrm{hr}$. incubation. The inability of the culture filtrates to attack collagen was not attributed to the use of an insufficiently concentrated preparation, for it was found that a culture filtrate of Clostridium histolyticum containing only $16 \mathrm{~m} . \mathrm{g} . \mathrm{d} . / \mathrm{ml}$. of gelatinase was able to dissolve with ease each of the collagen preparations which the $\boldsymbol{B}$. subtilis filtrates containing $\mathbf{5 0 0} \mathrm{m}$.g.d./ml. had failed to attack.

Table 1. In vitro and in vivo properties of a $1 \%(w / v)$ solution of dried culture filtrate from Bacillus subtilis after exposure to various temperatures

\begin{tabular}{|c|c|c|c|c|}
\hline & $\begin{array}{c}\text { Gelatinase } \\
\text { (m.g.d.) }\end{array}$ & $\begin{array}{c}\text { Hide powder } \\
\text { enzyme } \\
\text { (m.e.d.) }\end{array}$ & $\begin{array}{l}\text { Haemolysin } \\
\text { (m.h.d.) }\end{array}$ & $\begin{array}{l}\text { Dermonecroti } \\
\text { factor } \\
\text { (m.r.d.) }\end{array}$ \\
\hline Temperature & \multicolumn{4}{|c|}{ Residual activity/ml. after $15 \mathrm{~min}$. } \\
\hline $20^{\circ}$ & 240 & $640-1280$ & 40 & 8 \\
\hline $65^{\circ}$ & $<1$ & -- & 20 & $<1$ \\
\hline $70^{\circ}$ & $<1$ & $<1$ & 10 & $<1$ \\
\hline $80^{\circ}$ & - & - & 10 & - \\
\hline $100^{\circ}$ & - & - & $<1$ & - \\
\hline
\end{tabular}

Hide powder. Although the culture filtrates were unable to disintegrate native collagen they attacked degraded collagen in the form of hide powder. This was shown by the ability of culture filtrates to produce zones of clearing by the hole-plate method using hide powder in agar plates (Evans, 1947) and to liberate dye from 'azocoll' (Oakley, Warrack \& van Heyningen, 1946). The sensitivity of each of these methods was similar, and the activity of the hide powder enzyme was obtained by determining the minimal enzyme dose (m.e.d.) which produced a definite reaction. It was found that $1 \%(\mathrm{w} / \mathrm{v})$ solutions of dried culture filtrates contained about 500-1000 m.e.d./ml. The hide-powder disintegrating enzyme showed a sensitivity to the action of heat similar to that of gelatinase. A concentrated filtrate containing 600-1200 m.e.d./ml. lost its enzyme activity after it had been heated for $15 \mathrm{~min}$. at $70^{\circ}$ (Table 1 ).

\section{Action on other substrates}

Red blood cells. Culture filtrates were able to produce complete haemolysis of red blood cells. Three different species of R.B.c. were tested (rabbit, horse and guinea-pig) and were equally sensitive. Titrations of haemolytic activity were made in $0.15 \mathrm{M}$ phosphate buffer saline at $\mathrm{pH} 6 \cdot 9$ by adding $1 \mathrm{ml}$. of a suspension of well-washed red blood cells to $1 \mathrm{ml}$. of each of a series of enzyme dilutions. The mixtures were incubated for $1 \mathrm{hr}$. at $37^{\circ}$ in a water-bath and the minimal haemolytic dose (m.h.d.) determined from the highest dilution which produced complete haemolysis. Dried culture filtrates in $1 \%$ solution were found to contain about 40 m.h.d./ml. 
The haemolytic property of the concentrated filtrates was not as easily destroyed by heating as was the gelatinase activity. This is shown in Table 1 in which a comparison is made between the number of minimum reacting doses of gelatinase, hide powder enzyme and haemolysin in a filtrate which had been heated at various temperatures for $15 \mathrm{~min}$. It is evident that whereas the gelatinase and hide powder enzymes were completely destroyed after $15 \mathrm{~min}$. at $70^{\circ}$, the haemolytic activity was only decreased by $75 \%$. The Table also shows for comparison the effect of heat on the dermonecrotic property of the filtrate which is described in a later section.

Synovial fluid and lecithin. Filtrates were tested for hyaluronidase by the ACRA test (Burnet, 1948) and for lecithinase by the egg-yolk method (Macfarlane, Oakley \& Anderson, 1941). There was no evidence that either of these enzymes was present.

\section{INHIBITION OF IN VITRO REACTIONS BY NORMAL SERUM}

\section{Inhibition of gelatinase}

Since attempts were to be made to prepare antisera capable of neutralizing gelatinase activity it was necessary first to investigate the known inhibitory action (Bertiau, 1914) of normal sera.

The inhibitory reaction. Twofold dilutions of serum were made in saline and to $1 \mathrm{ml}$. of each dilution, $1 \mathrm{ml}$. of filtrate containing 8-16 m.g.d. was added. The mixtures were held at $37^{\circ}$ for $15 \mathrm{~min}$. in a water-bath, and then $2 \mathrm{ml}$. of $10 \%$ gelatin solution added to each mixture and incubation continued for a further $1 \mathrm{hr}$. Tests were read after the tubes had been cooled in the refrigerator and the highest dilution of serum which inhibited the liquefying action of the test dose of enzyme was determined. (In these titrations $1 / 1$ means undiluted serum and $<1 / 1$ is used when undiluted serum showed no activity.)

Table 2. Effect of time of incubation of serum and gelatinase, before addition of gelatin, on the titre of serum inhibitor

$\begin{array}{lccccc}\text { Period of incubation at } 37^{\circ} \ldots & 0 & 5 \mathrm{~min} . & 10 \mathrm{~min} . & 30 \mathrm{~min} . & 5 \mathrm{hr} \text {. } \\ \text { Titre of serum inhibitor } & 1 / 4 & 1 / 8 & 1 / 8 & 1 / 8 & 1 / 8\end{array}$

The inhibitory effect of fresh sera from seven different species (man, sheep, horse, ox, rabbit, guinea-pig and rat) was tested; with some of these species sera from several individuals were also tested. The inhibitory activities appeared to be a constant factor of normal serum, for in all tests the inhibitory titres were either $1 / 8$ or $1 / 16$. The inhibition of gelatinase by serum occurred in multiple proportions. This is shown in Fig. 3 by the linear relationship which was found to exist between the concentration of gelatinase and the dilution of serum which produced inhibition. The inhibitory action of serum was rapid. Tests in which gelatinase and serum were incubated for different times indicated that after $5 \mathrm{~min}$. the reaction reached an equilibrium which did not change on further incubation for periods up to $5 \mathrm{hr}$. (Table 2).

Stability of the inhibitor. Titrations of gelatinase inhibitor were made with serum which had been heated at various temperatures. Table 3 gives the result 
Table 3. Effect of heat on the gelatinase inhibitory activity of normal serum

$\begin{array}{lc}\begin{array}{c}\text { Treatment } \\ \text { of serum }\end{array} & \begin{array}{c}\text { Inhibitory } \\ \text { titre }\end{array} \\ \text { None } & 1 / 16 \\ 50^{\circ} \text { for } 60 \mathrm{~min} . & 1 / 16 \\ \mathbf{6 0} 0^{\circ} \text { for } 30 \mathrm{~min} . & 1 / 16 \\ \mathbf{6 0} 0^{\circ} \text { for } 60 \mathrm{~min} . & 1 / 8 \\ \mathbf{7 0} 0^{\circ} \text { for } 5 \mathrm{~min} . & <1 / 1\end{array}$

of a typical test, and it is evident that the inhibitor was only slightly affected by $1 \mathrm{hr}$. at $60^{\circ}$ but was rapidly destroyed at $70^{\circ}$.

The inhibitory action was also lost at lower temperatures although the rate of loss was not the same for all sera. Table 4 gives the inhibitory titres of a number of sera which had been stored at $5-10^{\circ}$ for a few months, and it is evident by comparison with fresh sera that there had been considerable loss of

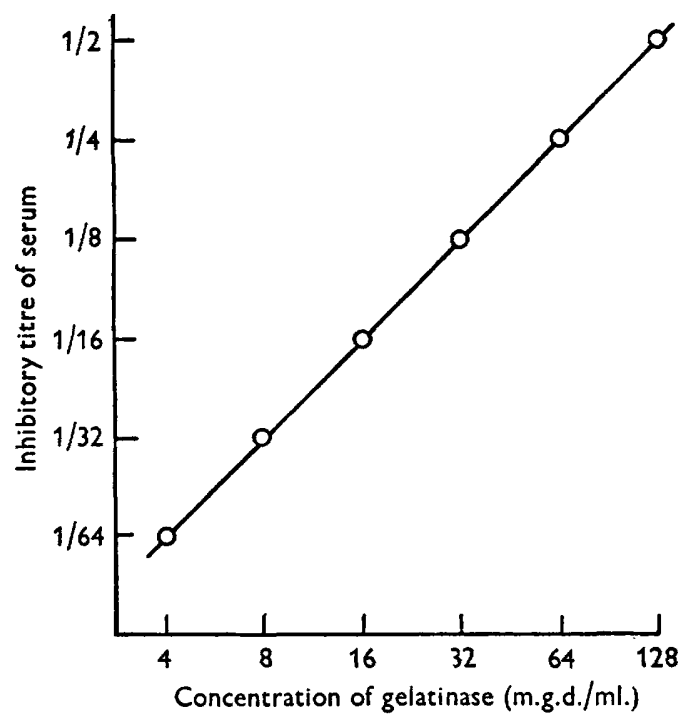

Fig. 3. The effect of various concentrations of gelatinase on the inhibitory titre of serum. Logarithmic scales are used for both axes.

inhibitory activity. The loss of inhibitory action was not due to the presence of $0.5 \%$ phenol added to sera as preservative, for tests made with a serum sterilized by filtration and stored with and without phenol, showed that the decrease in inhibitory titres occurred at the same rate in each case. When sera

Table 4. Gelatinase inhibitory titres of fresh and stored normal rabbit sera

$\begin{array}{cc}\text { Twenty-one fresh sera } & 14 \text { at } 1 / 16 \\ & 7 \text { at } 1 / 8 \\ \text { Twelve sera stored for } & 1 \text { at } 1 / 8 \\ 1-5 \text { months at 5-10 } & 2 \text { at } 1 / 2 \\ & 4 \text { at } 1 / 1 \\ & 5 \text { at }<1 / 1\end{array}$


were kept at $37^{\circ}$ the inhibitory effect was lost more rapidly. Sera from six rabbits each with an initial inhibitory titre of $1 / 8$ showed after 12 days at $37^{\circ}$ titres ranging from $<\mathbf{1 / 1}$ to $1 / 2$.

Comparison of gelatinase inhibitor with trypsin inhibitor. It is well known that serum has an antitryptic property, and the possible relationship of this property to the gelatinase inhibitor was investigated. This was done by comparing the trypsin and gelatinase inhibitory titres of fresh and stored sera. Typical results are given in Table $\mathbf{5}$, and it is evident from the varying ratios of the titres of gelatinase inhibitor to trypsin inhibitor that the factors responsible for these two effects were not the same.

Table 5. A comparison of the titres of gelatinase inhibitor and trypsin inhibitor of normal sera stored for various periods

$\begin{array}{lcccc}\text { Period } & \begin{array}{c}\text { Titre of } \\ \text { trypsin } \\ \text { inhibitory } \\ \text { activity }\end{array} & \begin{array}{c}\text { Titre of } \\ \text { gelatinase } \\ \text { inhibitory } \\ \text { activity }\end{array} & \text { Ratio } \\ \text { Serum } & \text { storage } & \text { (A) } & \text { (B) } & \text { (A:B) } \\ \text { R9 } & 1 \text { day } & 1 / 6 & 1 / 12 & 2: 1 \\ \text { R 10 } & 1 \text { day } & 1 / 12 & 1 / 12 & 1: 1 \\ \text { R63 } & 1 \text { week } & 1 / 6 & 1 / 12 & 2: 1 \\ \text { R26 } & \text { 4 months } & 1 / 6 & 1 / 1 & 1: 6 \\ \text { S1 } & 9 \text { months } & 1 / 12 & 1 / 6 & 1: 2 \\ \text { H1 } & 12 \text { months } & 1 / 3 & 1 / 1 & 1: 3\end{array}$

Inhibition of hide-powder enzyme and haemolysin

Preliminary experiments showed that the hide-powder disintegrating action and the haemolytic property of the filtrate were also inhibited by normal serum. Parallel titrations were made of the inhibitory action of a fresh normal rabbit serum using as indicators gelatin, azocoll and red blood cells. It was found that the inhibitory titres of the serum for gelatinase and hide-powder enzyme were identical at $1 / 14$, while the haemolytic property was inhibited by serum diluted to $1 / 50$. This result did not necessarily indicate that the haemolysin was distinct from the gelatinase and hide-powder enzyme since the filtrate contained a proportionately smaller number of minimal active doses of haemolysin, and therefore it might be expected that higher dilutions of serum would cause inhibition.

\section{IN VIVO PROPERTIES OF CULTURE FILTRATES}

\section{Necrotizing property}

The concentrated culture filtrates produced haemorrhagic necrotic lesions in the skin of rabbits (Pl. 1). A dose of $1 \mathrm{mg}$. contained in $0.2 \mathrm{ml}$. saline gave after 10-20 min. a flat area of oedematous induration $20-30 \mathrm{~mm}$. in diameter. The centre of induration became red and then dark purple, and after 1-4 hr. the skin broke down and serous fluid exuded freely from the lesion. After $24 \mathrm{hr}$. the area was covered with a dark dry necrotic plaque $10-20 \mathrm{~mm}$. in diameter. By injecting $\mathbf{0 . 2} \mathbf{~ m l}$. of a series of dilutions it was possible to titrate the necrotizing property of $1 \%$ solutions of concentrated filtrates, taking as 
the minimal reacting dose (m.r.d.) the highest dilution which produced a definite necrotic spot. The m.r.d. of the most potent preparations was $0.25 \mathrm{mg}$. The filtrates when diluted well beyond the end-point of necrosis still produced induration.

The thermolability of the necrotizing factor was similar to that of gelatinase. A filtrate containing 8 m.r.d. was no longer active after it had been heated for 15 min. at $65^{\circ}$ (Table 1).

The mode of action of the filtrates in producing skin necrosis has not been fully investigated, but the oedematous and haemorrhagic appearance of the lesions suggest that an increase in capillary permeability occurs at the site of injection. It was shown that the filtrates were, in fact, highly active in producing such an effect. This was done by titrating the filtrates intradermally in rabbits which had previously been given an intravenous injection of $4 \mathrm{ml}$. of a $5 \%$ saline solution of Pontamine Sky Blue BX (Gurr). An intense blue staining rapidly developed at the site of injection, due to the leakage of dyestained blood fluid into the cutaneous tissues. This effect was produced in less than $10 \mathrm{~min}$. by a dose containing only $0.001 \mathrm{mg}$. of dry filtrate.

\section{Lethal action}

The lethal action of dried culture filtrate preparations was titrated intravenously in 20-25 g. mice. With the most potent preparations the minimum lethal dose (m.l.d.) was $2.5 \mathrm{mg}$. in $0.4 \mathrm{ml}$. saline and death occurred in 5-9 hr. Filtrates which had been heated for $15 \mathrm{~min}$. at $65^{\circ}$ were non-lethal when given in a dose of $5 \mathrm{mg}$. A fuller investigation of the lethal action cannot be made until more potent preparations are obtained.

\section{ATTEMPTS TO PRODUCE ANTISERA TO CULTURE FILTRATES}

Attempts were made to produce in rabbits, guinea-pigs and rats, antisera capable of neutralizing the gelatinase activity of culture filtrates. Three rabbits, eight guinea-pigs and eight rats were injected subcutaneously at weekly intervals for 6 weeks with concentrated culture filtrates containing 400-900 m.g.d./ml. of gelatinase. The total number of m.g.d. injected into each rabbit, guinea-pig and rat was, respectively, 17,000, 4000 and 4000 . A second group containing two rabbits, eight guinea-pigs and eight rats was given a similar schedule of injections of whole living culture of $\boldsymbol{B}$. subtilis. The cultures contained on the average $16-32 \mathrm{~m} . \mathrm{g} . \mathrm{d} . / \mathrm{ml}$. of gelatinase, and each dose consisted of $10 \mathrm{ml}$. for the rabbits, $2 \mathrm{ml}$. for the guinea-pigs and $1 \mathrm{ml}$. for the rats. Samples of blood were taken from the animals 14 days after the last injection and the sera separated.

The sera were titrated for neutralizing action against gelatinase, using as controls sera from normal animals of the same species. The titration was made in the manner already described for estimating the inhibitory action of normal serum using a test dose of $1 \mathrm{ml}$. of filtrate containing 8-16 m.g.d. All the normal sera inhibited the gelatinase activity to the same titre of $1 / 10$. The sera from all inoculated rabbits, however, had a titre to $1 / 20$ which was shown 
by replicate tests to be a real difference. Similar differences were shown with sera from those guinea-pigs which received concentrated culture filtrate but not from those injected with whole culture. The sera from the inoculated rats all showed the same inhibitory titre as normal sera.

Those sera which showed titres higher than normal were titrated again after they had been held at $37^{\circ}$ for a month-a treatment which, we had shown, diminished the normal inhibitory activity. Normal sera subjected to the same treatment served as controls. The titres are given in Table 6 together with those obtained for the sera before treatment. It is evident that incubation had the effect of decreasing the titres of all the sera, but the residual titres of the

Table 6. Inhibitory titres of fresh and stored sera from normal and inoculated animals

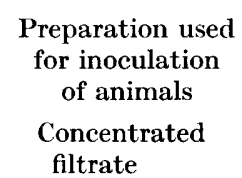

Culture

None

\begin{tabular}{|c|c|c|}
\hline \multirow[b]{2}{*}{ Animal } & \multicolumn{2}{|c|}{ Gelatinase inhibitory titres of serun } \\
\hline & Fresh & $\begin{array}{l}\text { After } 1 \text { month } \\
\text { at } 37^{\circ}\end{array}$ \\
\hline Guinea-pig no. 11 & $1 / 20$ & $1 / 10$ \\
\hline Guinea-pig no. 12 & $1 / 20$ & $1 / 10$ \\
\hline Guinea-pig no. 18 & $1 / 20$ & $1 / 10$ \\
\hline Rabbit no. 3 & $1 / 20$ & $1 / 5$ \\
\hline Rabbit no. 5 & $1 / 20$ & $1 / 2 \cdot 5$ \\
\hline Rabbit no. 1 & $1 / 20$ & $1 / 5$ \\
\hline Rabbit no. 2 & $1 / 20$ & $1 / 5$ \\
\hline Guinea-pig no. 19 & $1 / 10$ & $1 / 1$ \\
\hline Guinea-pig no. 20 & $1 / 10$ & $1 / 2 \cdot 5$ \\
\hline Rabbit no. 6 & $1 / 10$ & $1 / 1$ \\
\hline Rabbit no. 7 & $1 / 10$ & $1 / 1$ \\
\hline
\end{tabular}

sera from the inoculated animals were substantially higher than those of the normal sera. This is suggestive but not conclusive evidence that the sera from the inoculated animals contained, in addition to the normal inhibitor of gelatinase, a neutralizing factor which may have been the result of the inoculation. Although the inoculated animals may have developed antibodies to gelatinase there was no evidence that they had developed a resistance to the necrotizing action of filtrates. Intradermal titrations of culture filtrates in the inoculated rabbits produced necrosis as rapidly and to the same titre as in normal controls.

\section{DISCUSSION}

It has been known since the work of Bertiau (1914) that culture filtrates of B. subtilis possess the property of breaking-down gelatin, although little attention has been paid to their other properties. It is evident from our investigations, however, that there are a number of other definite activities associated with culture filtrates of this organism. So far only one strain has been used, but culture filtrates from this strain, with high gelatinase activity, contain an enzyme capable of breaking down degraded collagen in the form of hide powder and also a haemolysin active against the red blood cells of a number of different species. Further, the filtrates possess in vivo activities for they produce oedematous necrotic lesions on intradermal injection into 
rabbits and death on intravenous injection into mice. It is not yet known whether these in vitro and in vivo properties are associated with one and the same factor. A definite answer to this problem could be obtained if it were possible to produce neutralizing antisera, but so far we have no conclusive evidence that any of the factors is antigenic. We have, however, shown that the gelatinase, the hide-powder enzyme and the factors responsible for the in vivo reactions are similar in their thermolability, each being destroyed at $70^{\circ}$ for $15 \mathrm{~min}$., whereas the haemolysin appears to have a greater resistance to heat. This would at least suggest that the haemolysin is distinct from the other factors. On the other hand, the haemolysin appears to be similar to the gelatinase and hide-powder enzyme in that the activity of each of these three factors is inhibited by normal serum.

Although we have not yet been able to determine the relationship of the various in vitro and in vivo activities, it is interesting to speculate on the possible association of the 'proteolytic' properties with the production of dermonecrosis. The filtrates, although strongly active in breaking down degraded collagen in the form of gelatin and hide powder, were unable to affect native collagen and also unable to produce in vitro a softening effect on portions of skin. These observations suggest therefore that the disintegration and necrosis of skin following intradermal injection is not due to an enzyme in the filtrates which has a direct action on the collagen matrix of the skin, as is known to occur with the culture filtrates of $\mathrm{Cl}$. welchii, type A(Oakley, Warrack \& Warren, 1948) and $\mathrm{Cl}$. histolyticum (Oakley \& Warrack, 1950). Moreover, enzymes with the ability to break down gelatin and hide powder do not necessarily produce skin disintegration and necrosis since solutions of trypsin, 10 times more potent against gelatin and hide powder than $B$. subtilis culture filtrates, cause no necrotic reactions on intradermal injection into rabbits. It may be argued, however, that the inability of trypsin to produce necrosis is due to the fact that the enzyme is inhibited by serum, but such an argument does not apply as serum exerted a similar degree of inhibition against the 'proteolytic' action of the culture filtrates. It is therefore more probable that the development of skin necrosis was an indirect result of some other process occurring in the tissues. The filtrates were strongly active in producing a rapid increase in eapillary permeability; doses containing less than $0.001 \mathrm{mg}$. of dry filtrate gave intense reactions within 5-10 min. after intradermal injection into rabbits containing circulating indicator dye. This property of the filtrate may be of primary importance, and be responsible indirectly for the production of dermonecrosis, but whether it is associated with the 'proteolytic' activity of the filtrates remains to be investigated.

The ability of fresh normal serum to inhibit the in vitro activities of culture filtrates has presented some interesting problems. Inhibition occurred with each of the three in vitro activities which we have examined, although our investigations were mainly confined to the action on gelatinase. The possibility was considered that inhibition might be due to a neutralization by naturally occurring antibody, but the constancy of the inhibitory titres of sera from different individuals and species is scarcely in support of this view. There was 
also the possibility that inhibition was caused by the presence in serum of a lytic enzyme which destroyed gelatinase. Our experiments do not support this, since inhibition was complete in less than $10 \mathrm{~min}$. and did not progressively increase as would be expected of an enzyme reaction. A possible relationship of the gelatinase inhibitor to the trypsin inhibitor of serum was suggested by the fact that the inhibitory concentration of serum was directly proportional to the concentration of enzyme. This type of relationship was found for the trypsin inhibitor by Hussey \& Northrop (1923) who suggested a combination of molecules of trypsin and inhibitor in definite proportions to form a 'trypsininhibitor complex'. We found the trypsin and gelatinase inhibitors to be distinct, for it was possible by storage of sera substantially to reduce the gelatinase inhibitor without diminishing the antitryptic power.

So far we lack conclusive evidence that the gelatinase of B. subtilis is antigenic; sera from animals inoculated with large doses of concentrated filtrate or whole culture were only slightly more active in inhibiting gelatinase than normal sera. They gave strong precipitin reactions with the gelatinase preparations, but since these preparations were far from pure it would be difficult to attribute this reaction to gelatinase. The inability of the enzyme to produce antibody may be associated with its susceptibility to the inhibitory action of serum. Such an action may involve a combination of enzyme with serum proteins and if it occurred in vivo, would have the effect of converting the inoculated enzyme from a heterologous to a homologous substance. With this hypothesis in mind an attempt was made to maintain the gelatinase in a heterologous form by mixing it with sheep serum in sufficient quantity to inhibit its in vitro activity. Sera from rabbits inoculated with this mixture were, however, no more capable of neutralizing gelatinase than normal sera, although they contained precipitins in high titre for sheep serum. Antibodies to other bacterial gelatinases have been obtained which are inhibited by normal serum such as the $\lambda$-antigen of $C l$. welchii type B (Oakley et al. 1948); thus the lack of antigenicity shown by $B$. subtilis gelatinase need not necessarily be attributed to its inhibition by serum. The possibility of preparing antibodies to gelatinase by using adjuvants was also considered in view of the recent work by Duthie \& Lorenz (1952) who prepared antibodies to staphylococcal coagulase by inoculating rabbits with the enzyme adsorbed on to $\mathrm{AlPO}_{4}$. Our attempts, however, to adsorb gelatinase on to $\mathrm{AlPO}_{4}$ or $\mathrm{Al}(\mathrm{OH})_{3}$ were unsuccessful.

It is considered that the type of investigation described in this communication will be of value in the classification of species in the genus Bacillus. Other strains and species of the group may show characteristic differences in the in vitro and in vivo properties of their culture filtrates. We have already obtained evidence that the activities shown by $B$. subtilis filtrates in vitro on various collagen products are not completely reflected by some other actively 'proteolytic' species.

We should like to express our thanks to $\mathrm{Mr} \mathrm{H}$. Proom for strains of B. subtilis and to Dr G. H. Warrack for supplies of 'azocoll' and rat collagen paper. We are indebted to the Department of Medical Photography of the Manchester Royal 
Infirmary for the photograph. One of us (A.C.W.) wishes to acknowledge the receipt of a Studentship in Research Methods from the Medical Research Council.

\section{REFERENCES}

Bertiau, P. (1914). Les ferments bactériens qui liquéfient la gélatine et leur antiferments. Zbl. Bakt. (1. Abt. Orig.), 74, 374.

Burnet, F. M. (1948). The mucinase of V. cholerae. Aust. J. exp. Biol. med. Sci. 26, 71.

Delaunay, M., Guillaumie, M. \& Delaunay, A. (1949). Études sur le collagène. 1. A propos des collagènases bactériennes. Ann. Inst. Pasteur, 76, 16.

Duthie, E. S. \& Lorenz, L. (1952). Staphylococcal coagulase; mode of action and antigenicity. J. gen. Microbiol. 6, 95.

Evans, D. G. (1947). The production by certain species of Clostridium of enzymes disintegrating hide powder. J. gen. Microbiol. $1,378$.

Frazier, W. C. (1926). A method for the detection of changes in gelatin due to bacteria. J. infect. Dis. 39, 302.

Hussey, R. G. \& Northrop, J. H. (1923). A study of the equilibrium between the so called 'antitrypsin' of the blood and trypsin. J. gen. Physiol. 5, 335.

Macfarlane, R. G., OAKLey, C. L. \& Anderson, C. G. (1941). Haemolysis and the production of opalescence in serum and lecitho-vitellin by the $\alpha$-toxin of Clostridium reelchii. J. Path. Bact. 52, 99.

OAKLey, C. L. \& Warrack, G. H. (1950). The alpha, beta and gamma antigens of Clostridium histolyticum (Weinberg \& Séguin, 1916). J. gen. Microbiol. 4, 365.

OAKLey, C. L., Warrack, G. H. \& Heyningen, W. E. van (1946). The collagenase ( $\kappa$-toxin) of Cl. welchii type A. J. Path. Bact. 58, 229.

OAKley, C. L., Warrack, G. H. \& Warren, M. E. (1948). The kappa and lamda antigens of Clostridium welchii. J. Path. Bact. 60, 495.

\section{EXPLANATION OF PLATE}

Development of oedema and necrosis in the skin of a rabbit after four successive intradermal injections of $0.2 \mathrm{ml}$. of $1 \%$ solution of concentrated culture filtrate from $B$. subtilis. From left to right the injections were given $10 \mathrm{~min} ., 1 \mathrm{hr} ., 4 \mathrm{hr}$. and $24 \mathrm{hr}$. before the photograph was taken. $\times \frac{1}{2}$. 
Journal of General Microbiology, Vol. 7, Nos. 3 and 4

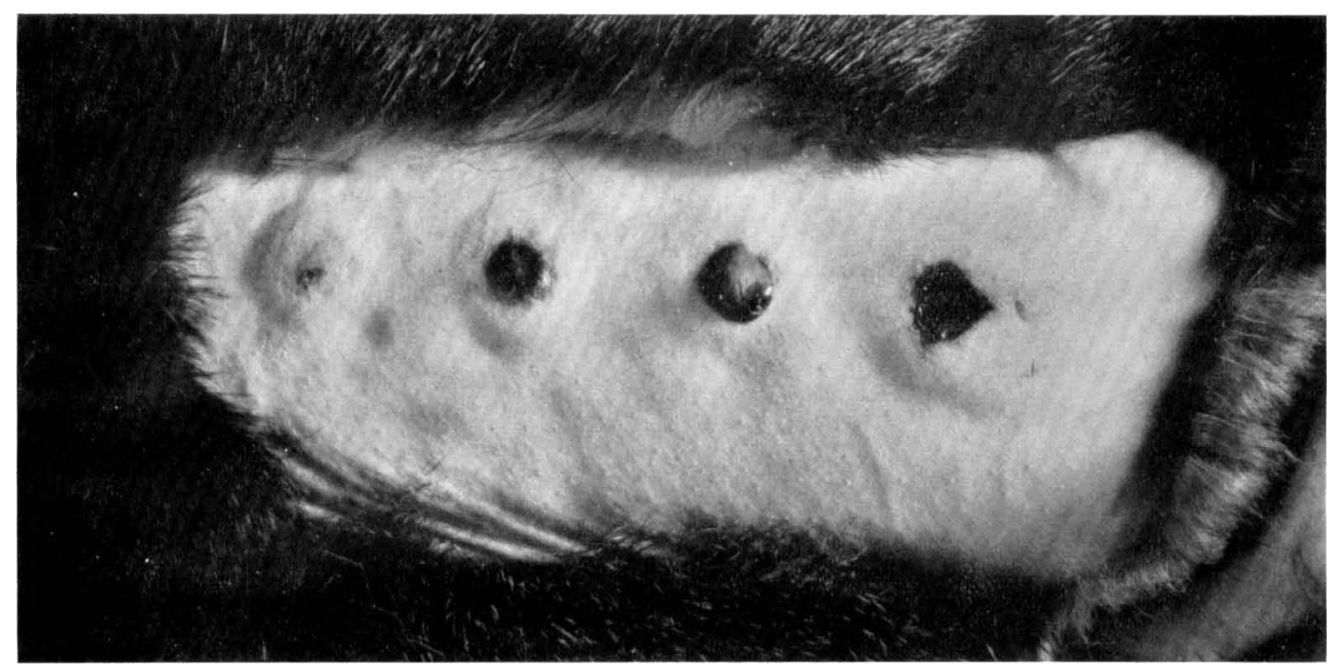

D. G. Evans \& A. C. Wardeaw-Propentues of B. subtilis culture filtiates. Plate 1 